\title{
Making Homes in Limbo? A Conceptual FRAMEWORK ${ }^{1}$
}

\author{
Cathrine Brun and Anita Fábos²
}

\begin{abstract}
This article aims to conceptualize home and homemaking for people in protracted displacement. The article serves three purposes: to present an overview of the area of inquiry; to develop an analytical framework for understanding home and homemaking for forced migrants in protracted displacement; and to introduce the special issue. It explores how protracted displacement has been defined-from policy definitions to people's experiences of protractedness, including "waiting" and "the permanence of temporariness." The article identifies the ambivalence embedded in experiences and practices of homemaking in long-term displacement, demonstrating how static notions of home and displacement might be unsettled. It achieves this through examining relationships between mobility and stasis, the material and symbolic, between the past, present, and future, and multiple places and scales. The article proposes a conceptual framework-a triadic constellation of home-that enables an analysis of home in different contexts of protracted displacement. The framework helps to explore home both as an idea and a practice, distinguishing among three elements: "home" as the dayto-day practices of homemaking, "Home" as representing values, traditions, memories, and feelings of home, and the broader political and historical contexts in which "HOME" is understood in the current global order and embedded in institutions. In conclusion, the article argues that a feminist and dynamic understanding of home-Home-HOME provides a more holistic perspective of making home in protracted displacement that promotes a more extensive and more sophisticated academic work, policies, and practices.
\end{abstract}

\section{Résumé}

L'un des buts de cet article est de conceptualiser l'idée de "domicile» ainsi que le processus d'établir un domicile pour personnes en situation de déplacement prolongé. Il répond à trois objectifs : présenter un aperçu actuel et récent $d u$ domaine en question, formuler un cadre analytique pour comprendre ce qu'un "domicile» et l'établissement d'un domicile peuvent représenter pour migrants forcés en déplacement prolongé, et introduire ce numéro spécial de Refuge consacré à l'idée du domicile dans l'impermanence. Il s'engage à explorer les diverses façons dont le déplacement prolongé a été défini, en allant des politiques sur le déplacement jusqu'à l'expérience vécue $d u$ prolongement et de l'impermanence, la condition $d$ "attente» et ce qu'on a nommé «la permanence $d u$ temporaire». L'article souligne l'ambivalence qui fait partie intégrale des expériences et pratiques visant à établir un domicile dans des situations de déplacement à long terme. Il démontre ainsi comment des notions figées de domicile et de déplacement pourraient être mises en mouvement, à travers une analyse des relations entre mobilité et fixité, entre le matériel et le symbolique, entre le passé, le présent et l'avenir, ainsi qu'une multiplicité de lieux et d'échelles. L'article propose comme cadre conceptuel une triple constellation des notions de domicile qui permet de les étudier dans des contextes variés de déplacement prolongé. C'est effectivement un cadre qui ouvre la voie à une exploration du concept «domicile», tant dans sa dimension théorique que pratique, en trois volets: «domicile» en lettres minuscules, c'est-à-dire l'aspect quotidien pratique que constitue l'acte d'établir un domicile; "Domicile» 
avec un «d» majuscule, représentant les valeurs, traditions, souvenirs, et sentiments qu'évoque un domicile; et enfin «DOMICILE» en lettres majuscules, signifiant le contexte politique et historique général à travers lequel le concept de domicile est intégré par l'hiérarchie du pouvoir de la mondialisation contemporaine, et incarné par les institutions. Pour conclure, l'article avance qu'une approche féministe et dynamique constituée de ces trois volets "domicileDomicile-DOMICILE» offre une perspective plus complète $d u$ processus d'établir un domicile dans des situations de déplacement prolongé, et conséquemment donne lieu à des recherches universitaires, ainsi qu'à des politiques et des applications pratiques, plus avancées et sophistiquées dans ce domaine.

\section{Introduction}

$\mathrm{T}$ This issue is a small attempt to take on a big dilemma: how-and why_do people who are living in ongoing displacement make homes. The dilemma is more than a problem of refugee policies ill-suited to the contemporary politics of "protracted refugee situations" (PRS) - a term that initially referred to people who spend years, possibly decades, in encampments and detention centres, but which we expand to include those forced migrants who go into "hiding" in urban areas, who are "in transit" from one place, one state, to the next, and who are subject to other "temporary" conditions such as unresolved residency permission. For refugees and forced migrants, the multiple urges for safety, for meaningful lives and livelihoods, and for belonging are not well served by the "permanence of temporariness," as these protracted liminal states have been called. 3

The tensions that accrue as a result of ongoing conflict, volatility, and flux from interactions between people on the move and the institutions, systems, and structures designed to manage particular types of human movement, lead to states of high uncertainty and social fluidity. This tension has profound effects on practices of homemaking in precarious circumstances, notions of "return" to a recognized home, and indeed the meaning of the term home itself. As a geographer and an anthropologist of forced migration, and as feminist scholars and practitioners, we have used our own fruitful collaboration to examine this dilemma from new-or newly synergistic-theoretical perspectives, as we mine disciplines and approaches towards understanding how, in practical terms, people in administrative limbo find the means and the capacity to carry on thinking about home and making home, despite their liminal and often dire circumstances. We further propose that a feminist understanding of homemaking may enable alternative humanitarian and policy approaches to shelter and meaningful inclusion.

In our introduction to this special issue of Refuge, we develop a conceptual framework of making homes in protracted situations of displacement. By challenging the common idea that long-displaced people are necessarily in limbo, we weave a critique of the policy context of protracted displacement in a globalizing world into our framework, and present a concept of "constellations of home" for mapping the complex and multiple understandings of home embedded in homemaking in protracted situations of displacement. We give examples of practices that illustrate the intersection of local meaning-making with national and supra-national notions of home.

This article has three main sections. We first explore the relationship between home and forced migration. We then turn to the notion of "protracted displacement," its magnitude, and implications of protractedness in a globalized world, before reflecting on people's experiences of living with protracted displacement. Finally, we place our conceptual framework of making home in protracted displacement within a feminist politics of place.

\section{Home and Forced Migration}

"In some sense, the narrative of leaving home produces too many homes and hence no Home, too many places in which memories attach themselves through carving out of inhabitable space, and hence no place in which memory can allow the past to reach the present (in which the "I" could declare itself as having come home)."4

Home and place are complex and interrelated notions, ${ }^{5}$ to which the experience of "forced migration" adds an additional layer to the puzzle of belonging and identity. Our understanding of place as open and dynamic comes from Doreen Massey. ${ }^{6}$ Brun notes that, for refugees and forced migrants, place is a particular articulation of social relations stretched out beyond one location. ${ }^{7}$ A place encompasses physical, social, economic, and cultural realities; a home in this understanding is "a particularly significant kind of place with which, and within which, we experience strong social, psychological and emotive attachments. ${ }^{8}$ Other recent contributions theorizing home and homemaking have brought a nuanced richness to the growing scholarship and broad interest in the topic. ${ }^{9}$ Blunt and Dowling, whose book outlining a "critical geography of home" emphasizes the relations between place, space, scale, identity, and power, bring much of this thinking together. ${ }^{10}$ Specifically, their formulation presents home as comprising two elements: home is a place, and also an idea and an imaginary imbued with feeling. "Home," propose Blunt and Dowling, "is thus a spatial imaginary, a set of intersecting and variable ideas and feelings, which are related 
to context, and which construct places, extend across spaces and scales, and connect places."11

This increased scholarly interest in home in the social sciences and humanities has led to a critical scrutiny of the often taken-for-granted and idealized notions of home as haven. Home is now established as a more unsettled and problematic entity where tension and conflict are replete. ${ }^{12}$ Home may be a house, but it may also refer to family, community, nation, and a number of other sites with which we associate and experience contingent acceptance. Home is thus not a site protected from the outside world; rather, its boundaries are porous ${ }^{13}$ and may be defined in relation to wider social and political locations. Home may be understood as a site in which power relations of the wider society, such as relations of gender, ethnicity, class, and generation are played out. As a case in point, people's displacement as a result of being targeted within their home country, and the deliberate damaging of civilian homes (referred to as "domicide"14) emphasize the political meaning of home. The forcible displacement of people from their houses, hometowns, and homelands highlights the importance of home at different scales and illustrates how unsettled the notion of the home as a safe haven becomes for forced migrants. Consequently, forced migration, the forcible displacement from places called home, becomes indicative of the experience of home as an unsettled, changing, open, and more mobile entity.

Our ongoing concern with home for migrants and mobile people continues to be enhanced by feminist thinking. Iris Marion Young's "House and Home: Feminist Variations on a Theme"15 illustrates how ambivalent the nature of home may be for those in subordinate positions-women, young people, or servants, for example. Taking Heidegger's "Building, Dwelling, Thinking" as her starting point, Young subjects the essay to feminist scrutiny and critiques its patriarchal ideology of a home in which the women's work of housekeeping helps to objectify women and "keep them in their place." Heidegger, according to Young, understands the human act of dwelling as comprising both cultivating and constructing, but his emphasis throughout the essay is on the latter rather than the former, which involves caring for, cherishing, protecting, and preserving. Women, whose roles are most often tied to cultivating, become a means through which men feel at home. Referencing Luce Irigaray, Young states, "In the patriarchal gender scheme, woman serves as the construction material"16 - that is, a woman's role is to be the home.

Inspired by Simone de Beauvoir, Young furthermore adds a time dimension to feminist theorizing of home. As cultivators of home, women-through their primary maintenance role-are confined to immanence through their cyclical, but unceasing, housework-an activity that is not viewed as future-oriented, or indeed as progress. Young points out that constructing (building), on the other hand, is an activity oriented towards the future, a future that is full of opportunities. This temporal distinction between cultivating in the present and building towards the futuretermed "transcendence"-bears close resemblance to the way protracted displacement has been theorized. ${ }^{17}$ Brun argues that protracted displacement in this context has often been understood as a separation of immanence and transcendence; people survive and continue their cyclical activities of cultivating as far as they can. However, for many, the future is so uncertain that they do not know how to engage in activities that may help them to invest in the future. ${ }^{18}$ For those forcibly displaced, understandings of home are often based on the past; people long for the home they lost, while past experiences of home influence the way home is envisaged in the future. ${ }^{19}$ Protracted displacement, then, often leads to the feeling of being stuck in the present. ${ }^{20}$ Hyndman and Giles ${ }^{21}$ propose that such "stuckness," indicated by legal limbo, encampment, and other securitization strategies that immobilize refugees over the long term, contributes to a "feminization of refugees"-a depiction of displaced people as helpless, passive, and static. We propose that this feminization discourse further associates refugees and their homemaking strategies with stasis and immanence.

Returning now to the gendered divide evident in Heidegger's concept of the dwelling, we apply Young's analysis of home to the circumstances in which forced migrants in protracted displacement find themselves. They-like women cultivating their home-appear to be confined to a maintenance role, nostalgic for their former lives. Eastmond"22 "reminds us that home moves us most powerfully as absence and negation." What may be felt most strongly as absence may be the social relations and practices possible to enact in a familiar "home" environment. ${ }^{23}$ This feeling of home as absence may be overpowering, even after many years displacement. However, the understanding of nostalgia as an unproductive yearning for what has been lost need not imply passivity. Dudley, ${ }^{24}$ for example, demonstrates that long-term refugees create a feeling of being at home by reconstructing the past home to come to terms with everyday life during displacement. Here, nostalgia is productive, supporting a desire for home in the present. ${ }^{25}$

Iris Marion Young's discussion of feminist everyday perspectives on home - the role of the material in understanding home and homemaking-is a perspective that has not been prominent in forced migration studies. ${ }^{26}$ In the articles that follow in this special issue, we respond to this shortcoming by incorporating the material dimensions of home and homemaking into our analyses, while still acknowledging 
the more traditional emphasis in forced migration on the idea of home. To understand the relational nature of the material and non-material during displacement, ${ }^{27}$ Brun's contribution to this issue, for example, addresses home as the dwelling. She engages with the role of materiality to understand the experience of home, the role of the dwelling-its location, size, and standard-in a process to move from shelter to housing for people in protracted displacement. Trapp's article (this issue) continues this discussion as she analyzes the complex relationship between the Liberian homeland and the route to, and through, America. She shows how Liberian refugees in Ghana build and furnish houses and adopt a lifestyle in Buduburam camp in Ghana representing material features of an imagined social life in America, but that is an intended precondition for an ultimate Liberian homecoming.

Forced migration studies has too often uncritically adopted the policy categories of refugees, internally displaced persons, and other terms as main categories of analysis. ${ }^{28}$ Key features of many narratives of forced migration within a sedentary metaphysics of the "national order of things" 29 have included the narrative of home as elsewhere, refugees as out of place, and the close association and inseparable bond between home and homeland. Nurturing such connections between home and forced migration has come as a result of, and contributed to, the fixing of people in place and the notions of limbo to which we return below. As with sedentarist notions of territorial belonging and the view of mobile people as "out of place," proposing an opposition between "home" and migration leads to home becoming a site or a place of fixity, with impermeable boundaries. To understand the relationship between home and movement without creating a dichotomy between migration as movement and home as stasis, we draw on Sara Ahmed's analysis $^{30}$ of the tension between home and movement. By complicating this oppositional understanding, Ahmed subverts the idea of migration and its use in theorizing identity as predicated on movement or loss. However, Ahmed does not simply advocate dispensing with any differentiation of home and away, since this suggests that whether one remains in or leaves a place in which one feels at home makes no difference to a person's identity.

While territorialized and fixed notions of home (spatially and temporally) continue to accompany understandings of displacement, scholars of forced migration have also helped to introduce a more fluid and dynamic conception of home by analyzing homemaking practices during displacement. Such studies challenge essentialist notions of home and away. ${ }^{31}$ Additionally, transnational and diaspora studies have influenced forced migration scholars to discuss home with an eye to multiple and extraterritorial ways of belonging. Home may be understood as "a process marked by openness and change,"32 and consequently we may find that home in forced migration focuses more on the relational and emotional perspectives of home rather than the territorial connections to a home. And, after many years of displacement, neither place of origin nor location of displacement may qualify fully as home. ${ }^{33}$ Home, according to Eastmond, is where normal life can be lived; it is a place that can provide economic security, a social context, and a sense of belonging. She shows how, for forced migrants, these qualities may be fulfilled only in the trans-local home, where it is the place of origin and the place of refuge that together represent home.

We propose that theorizing home and forced migration together allows for significant potential to revise our policies and thinking about refuge and home. We recognize that the separation between home and away for people fleeing from conflict is heartbreakingly visible, and that our international mechanisms for protecting people "unable ... or unwilling to return" to their place of habitual residence $^{34}$ has the effect of politicizing and essentializing the binary. Additionally, for many forced migrants in protracted displacement, trans-local practices may thus be restricted because people are fixed in place by policies and legal statuses that prevent movement and contact between the two homes. Nevertheless, even if people are restricted from moving between different places to construct complete, trans-local homes, they may still feel as though their home exists in multiple locations and may make distinctions between an "everyday home" and what Eastmond 35 terms a "cultural/spiritual" home. Often included, thus, in notions of home for forced migrants are feelings of longing for a different place, and memories of different places that come together in the practices of homemaking at the place of a present dwelling. At the same time, however, we suggest that homemaking at one location-for example, in a refugee camp-may be undertaken without necessarily including that location in a conception of home. Many of the dwellings and locations of protracted displacement are substandard or alien, and their inhabitants may never view them as home. Even if people are provided with more permanent living spaces in these contexts, they may feel "homeless at home,"36 since their ideal homes cannot be attained.

But home may also emerge in the making, and where home is experienced may shift, expand, or shrink as a result of displacement. Korac ${ }^{37}$ proposes two principles that further unsettle the binary between home and away and present home as a dynamic and temporal proposition. She first decouples "home" and "homeland" (territorial, nation state) in order to deconstruct refugees as people out of place (see also Capo, this issue). She then charges us to 
move beyond the notion of refugees as "constituted by their displacement" to allow us to understand how people create place in a mobile world. In this special issue, we aim to capture an open and dynamic notion of home in protracted displacement by presenting the different dimensions of home for forced migrants, from the material and territorial to the imaginary and symbolic. Now, however, we introduce the notion and challenge of protracted displacement and its associated policies.

\section{Protracted Displacement in a Globalized World}

The refugee and forced migration policy literature candidly describes the situation of protracted displacement has having "no solution in sight." 38 This description indicates an immobilized temporariness in which people "find themselves in a long-lasting and intractable state of limbo. Their lives may not be at risk, but their basic rights and essential economic, social and psychological needs remain unfulfilled after years in exile." 39 The term protracted refugee situation, or PRS, in the policy literature, initially referred to those populations of forced migrants granted refugee status by the international community but for whom a "durable solution"40 has yet to be implemented. At the time of UNHCR's creation, a core task was protecting and finding solutions for the people of Europe who had been displaced during the Second World War and who were still displaced in the late 1950 s. $^{41}$ While even then the UNHCR worried ${ }^{42}$ about the long-term displacement of refugees under its care,43 it managed by the 1960 s to provide resettlement quotas for European refugees who could not return or integrate locally-a precedent for addressing the contemporary "durable solutions" approach and a way of reorganizing displaced people back into places. Nevertheless, the other significant forcibly displaced population following the Second World War, the Palestinians, did not have a "place" to return to, for they were casualties of the unsuccessful 1948 UN Partition Plan and ensuing war between Israel and the Arab states.

The registered refugee population of Palestinians, dating back six decades and currently numbering over five million people living in 58 registered camps, ${ }^{44}$ is the most entrenched protracted refugee situation, but, notably, circumstances where large ${ }^{45}$ populations of co-nationals or co-ethnics have been in protracted situations of displacement are increasing, not decreasing. ${ }^{46}$ Nearly two-thirds of the world's refugees are in seemingly never-ending exile, with the average length of these states of "limbo" approaching 20 years. 47 Many more find themselves in towns and cities, often without access to formal legal protection, without assistance and consequently also often with precarious and risky livelihoods. In addition to the very visible phenomenon of large concentrations of displaced populations, such as the IDP camps in Darfur,
Sudan, and Dadaab and Kakuma refugee camps in Kenya, there is thus an equally important proportion of this group that is invisible. ${ }^{8}$ The majority of the world's protracted refugee situations are located in impoverished countries 49 and appear in Malkki's words as "vast zones of asylum."50 Malkki argues that "refugee camps are not 'test beds' of global segregations yet to come, but, rather, part and parcel of well-established international technologies of power for the control of space and movement. In those technologies, the refugee camp is 'standard equipment,' along with transit centers, reception centers, holding cells, prisons, labor compounds, ghettoes, and other familiar features of the modern sociopolitical landscape."51

The predominant response by the international community to large-scale refugee movements has been strongly criticized as the "warehousing" of human beings.52 According to this response model, dominating in the 1980s and 1990s, but currently continuing as the practice in many contexts, assistance is based on survival till the displaced populations are able to return-what Horst ${ }^{53}$ refers to as "don't die survival." Yet the majority of protracted conflicts do not offer the solution of "returning home" any time soon. The other "solutions" promoted by the international community-the incorporation of non-citizens, ethnic minorities, and others into the locale where they are based (termed "local integration" by the UNHCR), or the wholesale relocation of populations for "resettlement" in countries that offer a meaningful pathway to full membership in the polity (i.e., Australia, Canada, most European countries, and the United States)are still largely off the table. 54

While many of the known situations of protracted displacement are associated with encampments for refugees and internally displaced people, there are far more displaced people outside camps, who have produced and dwell in a variety of living spaces. The contributors to this special issue reflect some of this heterogeneity. In refugee camps, people tend to start off in tents and other temporary structures provided by the humanitarian regime, but these abodes are often developed by people themselves into more permanent structures and houses. In other cases, permanent houses based on UNHCR and similar standards are being built for displaced populations, described by Skotte as "tents in concrete," 55 but then subsequently modified by inhabitants. In the many cases where people do not live in organized settlements, the housing conditions may vary even more. These are often associated with low-standard housing, lack of tenure security as well as social security, and accompanied by fewer possibilities for modifying the domestic spaces and making homes. Fábos (this issue) describes the twotier urban housing structure in Cairo whereby Egyptians purchase flats most often as a function of marrying and 
establishing a new household, while "foreigners" (including refugees and other forced migrants) rent "furnished flats" shared by many people and sometimes located in squatter and other marginal settlements.

Adding to the precariousness of insecure living spaces for those in protracted displacement are policies believed to encourage people's willingness to return-or to be "put back into place." These policies commonly include restrictions to property ownership and limited access to other citizen rights, such as local restrictions to prevent people from becoming too permanently settled in an area. For example, while Egypt and Sudan have signed an agreement ${ }^{56}$ allowing citizens from either country freedom of movement, residence, work, and property ownership, Egypt seeks to limit implementation of the agreement to men between the ages of 18 and 49. Egypt has also issued a number of laws regulating, restricting, or banning property ownership by foreign nationals, most recently in 2012 when foreign rights to ownership of land in the Sinai Peninsula were discontinued.57 As Capo shows in her article in this special issue, the term durable solutions needs to be unpacked in the light of current conflict realities and politics of mobility. Considering the tension between various policy regimes' attempts to "fix" people in place, the unintended consequences of policies and the mobile practices that many displaced people pursue in making home during displacement, all contributors to this special issue see the need to understand protracted displacement and the making of home quite differently from the perspectives developed when the refugee convention and subsequent policies were formulated.

It is well established that the political organization of identities into nation-states, and the forced migration of those nations' Others are outcomes of struggles over national identity and a feature of population management through refugee regimes and accompanying immigration, naturalization, and citizenship policies. Inclusion and exclusion in the everyday practices of statecraft influence which types of people are allowed into national spaces, which types of people are kept outside, and on what conditions people are allowed to stay. A range of forced displacements, including persons internally displaced as the result of civil conflicts as well as nationbuilding (i.e., development-induced forced displacement) can be linked conceptually to the creation and policing of borders and the liminal position of groups of people who fall between categories of population and citizenship management.

\section{Living in Protracted Displacement: Immobilized Temporariness}

"Limbo" has become a common description of protracted displacement and gives the impression of a fixed, locked, and consequently static situation in which people wait for a better life..$^{8}$ Protracted displacement for people is often described as existing "betwixt and between" a former home and a new home, a previous social setting and a receiving society, a homeland and a country of refuge. And many displaced people tend to describe their experience using similar binary terms. Yet, in this seemingly static set of circumstances, homemaking nevertheless takes place as people try to recreate familiarity, improve their material conditions, and imagine a better future. The authors in this special issue are concerned with notions of home and the material day-to-day practices that people in displacement pursue to survive and move on, and demonstrate that, even in waiting, people continue to challenge static arrangements, long for and imagine a home located somewhere else, and make home in exile. The overall perspective from the empirical material emerging from the contributions is a departure from the conception of protracted displacement as "limbo." In order to understand the ways in which homemaking practices take place during displacement, we shift towards a vocabulary of liminality 59 that captures the simultaneous processes of marginalization, control, and stasis on the one hand, and transformation and flows on the other. In taking up this vocabulary, we point to the political potential in formulating a dynamic understanding of home, an understanding that contests the policy understanding of protracted displacement as limbo and rather focuses on the ways in which notions of home are formulated and reformulated during displacement.

In this article, the notion of "limbo" and its inherent fixity-geographical and temporal-come under scrutiny. By incorporating movement, transgression, and transformation into the notion of protracted displacement, we propose that the extended temporariness of "home" for forced migrants in protracted situations may be understood not as limbo, but as a form of "liminality"-a concept occasionally used in the literature on refugeeness to help theorize the "place" of refugees and forced migrants, both in geopolitical terms and with regards to notions of social roles and cultural belonging. ${ }^{60}$ According to anthropological theorizing, the quality of being in a liminal state-betwixt and between accepted social categories and the norms and expectations linked to those categories - is profoundly threatening to the social order. The usual application of the concept of liminality is in regard to the social rituals that mark transitions between life stages - from adolescence to adulthood, or from an unmarried to a married state, for example. The expectation for those proceeding through rites of passage is that, however difficult the transition may be, there is the promise of movement to another state of being and belonging. The concept of liminality has also been used to help explain why groups out of place in the social order (i.e., people with 
mobile or itinerant livelihoods, such as peddlers or musicians) are often treated as having threatening or polluting qualities, since their embodied roles are in a process of uncertainty, transformation, and flux, and powerful social actors are not entirely able to exert control. ${ }^{61}$

Theorists of forced migration who have identified "the refugee" as a liminal category in the nation-state system-most notably Liisa Malkki, ${ }^{62}$ whose work has inspired a generation of forced migration scholars-observe how mobile people "out of place" are imbued with similar qualities of dangerousness, including the treatment of refugees as a security threat to borders, refugees as a threat to public order, and refugees as criminal elements. The long-term persistence of forced migrants "out of place" creates an existential threat to the global order. Mortland describes refugee camps as "an international strategy for dealing with the 'fallout,' the 'refuse' of international crises; as such, they mark physically and symbolically the transition of human beings between societies."63 Hyndman and Giles ${ }^{64}$ point out that the particular policies of fixing displaced people in sedentarist metaphysics underscores Malkki's notion of people on the move as a threat. They have eloquently shown how policies that fix people in place create feminized spaces of encampment that maintain protracted situations of displacement rather than contribute to enable people to escape the limbo created materially, discursively, and politically by the refugee regime.

As we have noted, the feminization of encamped refugees further supports "the attribution of certain programs, practices and identities as passive, helpless, static."65 "Fixing" people in camps and "safe places" reduces the threat that people's temporary status represents. In this context, Kibreab ${ }^{66}$ provides several examples of forced migrants in the Greater Horn Region of eastern Africa who have opted out of regulatory processes that accompany refugee policies of the international community, such as the thousands of Eritreans in Sudan who either have left formal refugee camps for cities and provincial towns or eschew them altogether. ${ }^{67}$ These individuals, while highly mobile and agentive, are also vulnerable to abuse, detention, and deportation as a result of their "in-between" legal status; because they are neither citizens of their countries of residence nor registered refugees, their conditions of homemaking are precarious and liminal, even though outside the gaze of the international refugee regime. The liminal spaces we study here are located "between vulnerability and agential power," and represent "the ambiguous, grey zone between the inside and outside, the social condition of neither fully excluded nor fully recognized." 68

Despite the vulnerable legal position and precarious socio-economic and political circumstances of forced migrants in protracted situations, contributors to this special issue demonstrate that, contrary to the static notion of limbo, the work of homemaking at a number of levels does not cease. Shifting our discussion from limbo to liminality indicates a more unsettled relationship between fixity and motion in the experience and practices of protracted displacement. We connect our thinking about people "out of place" to the concept of "mobility" as a way for scholars of forced migration to inquire how homemaking might open up a transformative political space for people in protracted refugee situations. Thinking about mobility helps us to theorize the relationships between movement, people, and places, even when people are unable to move-for example, in protracted refugee circumstances-and to apply these ideas to possibilities for creative engagement with powerful state and humanitarian actors, as well as the quotidian practices of homemaking. Herein lies the dynamic and open understanding of home that was introduced above.

Forced migration studies is beginning to address the tension between fixity and motion prominent in the "new mobilities paradigm." ${ }^{69}$ Still, there is little published work that grapples explicitly with the empirical and theoretical intersections. In this special issue, the contributions help to provide an understanding, not of the tension between fixity and motion, but rather of the important relationship and dynamics between them for the experience of protracted displacement and the associated practices of making home that we explore here. Being on the move does not mean that people do not dream of or aim for a more stable life and a fixed material and territorial entity ${ }^{70}$ that they can call home. Protracted displacement involves living with an uncertain future in the context of conflict and mobility. Vigh's concept of social navigation ${ }^{71}$-the observation that people are not only "on the move" in multiple ways, but that they must constantly interact with a "moving environment" - connects the notion of mobility to circumstances of insecurity, uncertainty, and volatility. Examining the empirical evidencebased arguments from our authors' research, we suggest that the people in the protracted situations under study are experiencing extraordinary flux even in their immobilized states, and the metaphor of navigating the "moving environment" here is apropos of these dynamic conditions.

The theoretical tools of mobility are applicable to assessing a range of homemaking strategies of people in "immobilized temporariness" at different scales. Our contributors attend to the scalar variations of mobility through analyzing such local creative practices as transforming temporary shelters to places of homely meaning (see Brun, this issue), as well as through looking at transnational practices that connect past and future homemaking imaginaries to present experiences of "managing limbo" (see Trapp, this issue). Ethno-national tropes of belonging have long underpinned international 
policies of "return" for refugees, and Capo's article (this issue) allows us to view critically, from the perspective of refugees from former Yugoslavia who were "returned" to their ethnic homelands, the idea of a "durable solution" to the predicament of displacement. Continuing to practise mobile strategies that incorporate pre-war settlements and houses, the homemaking of these forced migrants straddles two territories in two or more countries (Capo, this issue) but does not completely erase feelings of temporariness, of liminality.

The empirical analyses and theoretical observations of our colleagues in this issue help us to get beyond the notion of protracted circumstances of displacement as stasis or "limbo." We incorporate the real concerns for those who are "stuck" in liminal categories, the processes of marginalization that comes with being kept in waiting, and the attendant dilemmas of belonging and practical limitations of current refugee and forced migration policy with an understanding of what Brun ${ }^{72}$ terms "agency-in-waiting," the creative work done by forced migrants to get on with the process of homemaking in protracted displacement.

\section{Constellations of Home}

The current political context determines "place" and "emplacement" in such a way as to render large groups of people "out of place" even while "fixed in place," and has given rise to the "no solution in sight" policy limbo of protracted refugee situations. And yet, the lives of these warehoused individuals and families go on, with all of the attendant quotidian acts, social practices, and meaningmaking. This very human capacity to navigate uncertainty 73 is wielded even while governments, international agencies, and local administrations treat these situations as "fixed" and their occupants as "in limbo." For immobilized forced migrants, this includes engaging with the concept of home. As our authors demonstrate, many people in situations of protracted displacement will continue to organize their daily lives and think about their futures, even while their abilities to plan appear curtailed, and while their homemaking practices are shaped by hardship and uncertainty. Our authors' research finds that homemaking for refugees and displaced persons is rather like a dialogue that spans place and time, incorporating ideal concepts of home and the homeland, aspirations to return "home," and hopes to achieve a more stable exile by strategizing to go somewhere else or return. We suggest that these multiple concepts exist simultaneously while the people who hold them move among different locations to form a very complex idea of home that we have called "constellations of home."74 The metaphor of constellations is useful here to demonstrate how human beings turn points of reference into meaningful patterns, but that the same points may be imagined differently from each site of observation.

Building upon the literature on home and forced migration and the insights from experiences of protracted displacement, we have derived a simplified triadic constellation that may help us to think about the interconnected and multidimensional implications of homemaking in protracted circumstances of displacement. To distinguish between the different strands that make up this constellation, we visually code them as "home," "Home," and "HOME." Beginning with "home," we take this to mean the day-to-day practices that help to create the place of displacement as a particularly significant kind of place..$^{75}$ Such practices involve both material and imaginative notions of home and may be improvements or even investments to temporary dwellings (Brun, Trapp, this issue); they include the daily routines that people undertake in these dwellings; and they incorporate the social connections people make in a neighbourhood, a section of a camp or other institutions formed to "take care of" refugees and IDPs. Capo (this issue) shows the importance of re-establishing the everyday for ethnic Croats in order to make newly transnational homes in exile and return as a way of rekindling a sense of security-both physical and economic. ${ }^{76}$ Homemaking practices do not necessarily take place in a dwelling: Fábos (this issue) discusses how visiting patterns knit Muslim Arab Sudanese forced migrants together through mobile practices that span significant distances across urban space, while Donà (this issue) challenges the notion of "home" as physical domesticity and shows that displacement may lead to a shift in homemaking practices away from the dwelling and towards non-territorialized settings such as online communities. The feminist observation that women and men imagine domesticity differently and that the labour of homemaking is gendered reminds us that home is also the site of power relations and domestic inequity. The dynamics of displacement we study here, including changes in gendered relations of power, help to show the multiple and often ambivalent ways in which homemaking practices transform notions of home during protracted displacement. Together, the homemaking practices analyzed in this special issue help to bind material and non-material values and experiences of the home. As such, "home" in long-term displacement must also be understood in relation to other points of reference within meaningful constellations for people in circumstances of permanent temporariness.

The second modality in our constellations of home formulation, "Home," represents values, traditions, memories, and subjective feelings of home. Discussions of home and displacement tend to concern an ideal Home, the Home that many displaced people dream of and long for (see, Trapp this 
issue). We have shown above that these ideas of home are created by the experiences displaced people have of lost homes, past homes, and their dreams and hopes for future homes. The Home articulated during protracted displacement refers to a more generalized ideal in a particular socio-cultural context and influences domestic practices in temporary dwellings as the authors of this special issue explore. Emerging from the ideal Home are the material standards a dwelling must have for it to be inhabitable; while some minimum standards may be commonly shared across socio-cultural contexts, certain aspects such as what constitutes privacy may vary widely. The ideal Home for forced migrants in protracted situations is then reflected in the dwelling, but is also expressed at different scales. For example, numerous studies on home and diaspora analyze the ways in which nostalgia and longing for the "homeland" nurture an ideal, "idealized," or even invented Home.77 The contributions to this special issue identify a similar nostalgia for Home that operates concurrently with people's conceptions of the ideal dwelling and of the homeland. This relationship between dwelling and homeland is exemplified by Trapp (this issue) who unpacks the complex relationship for Liberian refugees in Ghana between their Liberian homeland and the United States as a way station to Home through her analysis of camp dwellings that are said to be "already in America." Capo (this issue) furthermore juxtaposes her own ethnographic research on home and homecoming among Croats from Serbia with studies on home and homecoming among Serbs from Croatia and Croats from Bosnia to understand the gap between people's everyday notions of home and the politicized notions of home dominating scholarship in the Balkans.

Finally, grappling with homemaking in protracted displacement requires engaging with the dominant meaning and institutionalization of HOME for the current global order. While we recognize that the notion of "homeland" is highly politicized for forced migrants idealizing their Home, our focus on the modality coded here as HOME refers to the broader political and historical context in which home is understood and experienced not only by displaced people, but also by the perpetrators of nationalist exclusion and violence and the policy-makers addressing protracted displacement through the optic of "durable solutions." It refers to the geopolitics of nation and homeland that contribute to situations of protracted displacement and the ways in which politics of home are necessarily implicated in the causes of displacement. Including HOME in our constellation makes the rift between assumptions about displaced people in a (largely) fixed global order and the fluid conditions of precariousness and unsettledness more visible.

Together with the ideal notion of Home as homeland, HOME requires an understanding of the status assigned to displaced populations in a particular society, the ways in which displaced populations are governed and disciplined by the state, its norms and technologies that privilege official status and sedentarism, and associated politics of inclusion and exclusion. HOME indicates how people conform with, negotiate, challenge, and change the labels assigned to them, and thus, finally, HOME signifies the dynamics of identity formation at community and individual levels that often take place during displacement as a result of the experience of loss of home on the one hand, and the experience of being labelled IDP or refugee on the other hand.

In capturing the dynamic processes of making home in the politically "fixed" circumstances of protracted displacement, the contributions to this special issue recognize that these understandings of home are analytically difficult to separate and are often presented together by forced migrants in the way they make home during displacement. However, the modalities of home, Home, and HOME, while produced simultaneously, mutually influence each other in different ways in the cases presented here. Varying with the context, the points of reference in a constellation of home are given different weight; accordingly, depending on where the centre of gravity lies within the different dimensions of home, the constellation changes from context to context. Making home in long-term displacement is thus given different forms and configurations, depending on the spatial and temporal context. The "constellations of home" that our contributors think through and analyze therefore produce different strategies of homemaking in the liminal circumstances specific to each interrelationship between the three meanings of home represented above.

\section{Making Home in "Limbo"? A Feminist Proposition}

In this introduction we have addressed understandings of how-and why-people in protracted displacement navigate the process of making homes. We have pointed to two fundamental dilemmas in the relationship between home and displacement. First, what tools do we as scholars, practitioners, and forced migrants have to help us understand, theoretically, the relationship between home and movement without resorting to a dichotomy between migration as movement and home as stasis? Second, how can we overcome the policies of stasis and fixity, with their structural manifestation in durable solutions as the bedrock of homethat have played such a strong role in creating the limbo of PRS? Inspired by new thinking in migration studies and feminist studies, our conceptual framework of "constellations of home" demonstrates ways in which the "problematic and fluid nature" of home can be analyzed and theorized $^{78}$ in the specific context of displacement, but also more generally in a shifting and changing global context. We 
propose that thinking about constellations of home allows for a more holistic exploration of how and where processes of making home in protracted displacement take place. We also assert that a dynamic understanding of home in protracted displacement enables new possibilities for reflecting on homemaking practices during displacement. The contributors analyze (in different contexts) the ways in which particular constellations of home-relationships between home-Home-HOME-produce specific notions of home and specific strategies for making home that challenge perceptions and policies of fixity and limbo and unsettle the dichotomy between stasis and movement.

While contributing to a general debate about home and forced migration, this special issue also challenges the ways in which nation-states and the "inter-national" community employ encampment, minimum standards, and "don't die survival" to address unending displacement-a predicament that has emerged from the problematique of viewing PRS as limbo and forced migrants as out of place. This lens leads states, policy-makers, and humanitarian actors to use essentialist and static notions of home that continue to fix forced migrants in both place and time, depriving them of agency and the opportunities to move on and make homes in displacement. The continued policy use of the term limbo to refer to protracted situations of forced migration additionally underscores the gendered geopolitics of forced migration management at the global scale. A feminist approach to the agentive work of making home helps us to unpack the gendered aspects of control inherent in policies that derive from such a static understanding of home. We are proposing a more dynamic understanding of home in this special issue. Here, making home is not the same as homemaking practices, which is only one dimension of the concept of home as we have identified above. "Making home" refers to the particular ways in which home is constituted in protracted displacement through the dynamic relationship between home-Home-HOME. Making home represents the process through which people try to gain control over their lives and involves negotiating specific understandings of home, particular regimes of control and assistance, and specific locations and material structures.

If our notion of HOME requires new thinking about how the very systems of administering and regulating mobilities are inculcated in the ongoing displacement of people, then a feminist politics of security, border management, and migration addresses some of the gendered assumptions inherent in viewing mobile people as masculinized threats to the social and political order. Similarly, policies in support of exilic nostalgia for an ideal Home often foster exclusive visions of the homeland that recreate-or create anewheroic narratives of belonging with associated normative gender relations that punish hybridity, dissent, or withdrawal. Exile politics directed at a return to the homeland have often been the purview of the masculine, with sometimes dire results for members of diasporic communities whose alternative visions of an ideal Home are viewed with suspicion or worse. ${ }^{79} \mathrm{~A}$ feminist analysis of Home speaks to the possibilities for more nuanced imaginings of the homeland, and the ideal domicile as an inclusive space. Finally, a feminist analysis of the day-to-day practices and domestic experiences of forced migrants in ongoing circumstances of displacement would be attentive not only to their gendered differences-in access to resources, division of labour, and use of space-but also to the humble creative work of domesticity in the face of politicized neglect. Attending to the specific ways that people live agentive lives in administrative limbo, and to the inseparability of their domestic practices from the oftentimes masculine politics of exile and global responses to displacement, we argue, carves out a crucial space for challenging international systems and structures and their policies of limbo. For the millions of people living in the liminal circumstances of PRS, making home involves and even requires a constellation of efforts.

Home is furthermore an intimate dimension of people's lives, involving private spaces as well as public meaningmaking, and requires what Miller ${ }^{80}$ terms studying "behind closed doors." Although our conceptualization of home as a multi-scalar and multi-temporal assemblage tempers the artificial binary of the public/private, we nevertheless need to come in close to understand the role of the different dimensions of home. Ethical dilemmas are abundant in this context, and Trapp (this issue) mentions how the line between the status as an outsider and insider is a very narrow distinction when examining how the researcher organizes her own living spaces while conducting fieldwork. Methodologically, much of the research is ethnographic, involving living with people (Trapp, this issue), following people's lives over time (Brun, this issue), accompanying them in their everyday movements/mobilities (Fábos, this issue), as well as joining them in new/non-territorial locations for the production of home (Donà, this issue). Understanding the making of home through constellations of home requires locating those ethnographies in a wider context, and the authors in this special issue engage with a range of methods to create this wider understanding of political context.

Our major contribution to the understandings of making home is thus to bring the focus onto the politics of immobilized temporariness for people who nevertheless continue to think of home as existing in a range of different places across space and time and act within circumscribed geographic, historical, and political contexts to create domestic 
spaces. In order to study the making of home during displacement, the contributors have engaged with the constellations of home in various ways: empirically, theoretically and methodologically. In viewing a constellation of stars, the image appears flat, with all of the stars appearing the same distance away. However, were we to come closer to the astral cluster, some stars are discovered to be closer and some more distant. Similarly, for forced migrants reimagining home in protracted displacement, the various nodes of home-Home-HOME may retreat, emerge, or reappear in different configurations over time. It is through an exploration of these processes of making home in immobilized temporariness that the articles to follow extend our understanding of how notions, experiences, and feelings of home are manifested, challenged, and changing, despite the liminality of unending displacement.

Cathrine Brun, Department of Geography, Norwegian University of Science and Technology

Anita Fábos, Department of International Development, Community, and Environment, Clark University

\section{Notes}

1 This special issue, and the collaborative work to frame home-making for people living in protracted physical, political, and/or legal circumstances of displacement was first presented at the 14th International Association for the Study of Forced Migration conference in Kolkata, India. Special thanks to Jennifer Hyndman and Tania Kaiser for their incisive comments on earlier drafts. Finally, appreciation is due to two anonymous reviewers whose suggestions have strengthened and enhanced the final version.

2 Equal authorship

3 Baruch Kimmerling and Joel S. Midgdal, Palestinians: The Making of a People (New York: Free Press, 1993), 279.

4 Sara Ahmed, "Home and Away. Narratives of Home and Estrangement," International Journal of Cultural Studies 2, no. 3 (1999): 330-1.

5 See a more extensive discussion by Hazel Easthope, "A Place Called Home," Housing, Theory and Society 2, no. 3 (2004): 128-36.

6 Doreen Massey, "A Global Sense of Place," Marxism Today June (1991): 24-9; Massey, Space, Place and Gender (Cambridge: Polity, 1994).

7 Cathrine Brun, "Reterritorialising the Link between People and Place in Refugee Studies," Geografiska Annaler 83B, no. 1 (2001): 15-25.

8 Easthope, "Place Called Home," 135-6.

9 Katherine Brickell, "Mapping” and 'Doing' Critical Geographies of Home," Progress in Human Geography 36, no. 2 (2012): 225-44; Alison Blunt and Robyn Dowling, Home
(Abingdon: Routledge, 2006); Ann Varley, "A Place Like This? Stories of Dementia, Home, and the Self," Environment and Planning D: Society and Space 26 (2008): 47-67; Geraldine Pratt, "Geographies of Identity and Difference: Marking Boundaries," in Human Geography Today, ed. Doreen Massey, John Allen, and Phil Sarre (Cambridge: Polity, 1999), 151-67; Paul Basu, "Hunting Down Home: Reflections on Homeland and the Search for Identity in the Scottish diaspora," in Contested Landscapes: Movement, Exile and Place, ed. B. Bender and M. Winer (Oxford: Berg, 2001), 333-48; Jennifer Hyndman, ed., "Authors Meet Critiques. Review and Responses. Alison Blunt and Robyn Dowling. Home," Social and Cultural Geographies 9, no. 5 (2008): 557-72.

10 Blunt and Dowling, Home.

11 Ibid., 2.

12 Brickell, “"Mapping' and 'Doing.”

13 Maria Kaika, "Interrogating the Geographies of the Familiar: Domesticating Nature and Constructing the Autonomy of the Modern Home," International Journal of Urban and Regional Research 28, no. 2 (2004): 265-86.

14 Douglas Porteous and Sandra E. Smith, Domicide: The Global Destruction of Home (Montreal and Kingston: McGill-Queen's University Press, 2001).

15 Iris Marion Young, "House and Home: Feminist Variations on a Theme," in On Female Body Experience: Throwing Like a Girl and Other Essays, ed. Iris Marion Young (Cary, NC: Oxford University Press, 2005), chap. 7.

16 Ibid., 129.

17 See Brun, this issue; Cathrine Brun, "Active Waiting and Changing Hopes: Toward a Time Perspective on Protracted Displacement," in "Conflict, Mobility and Uncertainty," ed. C. Horst and K. Grabska, special issue, Social Analysis 59, no. 1 (2015): 19-37.

18 Brun, "Active Waiting and Changing Hopes."

19 See, for example, Peter Kabachnik, Joanna Regulska, and Beth Mitchneck, "Where and When Is Home? The Double Displacement of Georgian IDPs from Abkhazia," Journal of Refugee Studies 23, no. 3 (2010): 315-36.

20 Brun, "Active Waiting and Changing Hopes."

21 Jennifer Hyndman and Wenona Giles. "Waiting for What? The Feminization of Asylum in Protracted Situations," Gender, Place and Culture 18, no. 3 (2011): 361-79.

22 Marita Eastmond, "Transnational Returns and Reconstruction in Post-war Bosnia and Herzegovina," International Migration 44, no. 3 (2006): 141-66, cited in Maja Korac, Remaking Home: Reconstructing Life, Place and Identity in Rome and Amsterdam (Oxford: Berghahn Books, 2009), 28.

23 Tania Kaiser, "Social and Ritual Activity in and out of Place: The 'Negotiation of Locality' in a Sudanese Refugee Settlement," Mobilities 3, no. 3 (2008): 375-95.

24 Sandra Dudley, "Feeling at Home: Producing and Consuming Things in Karenni Refugee Camps on the ThaiBurma Border," Population, Space and Place 17, no. 6 (2011): 743 . 
25 Alison Blunt, "Collective Memory and Productive Nostalgia: Anglo-Indian Homemaking at McCluskieganj," Environment and Planning D: Society and Space, 21 (2003): 717-38.

26 Dudley, "Feeling at Home."

27 Kaiser, "Social and Ritual Activity."

28 See especially Oliver Bakewell, "Research beyond the Categories: The Importance of Policy Irrelevant Research into Forced Migration," Journal of Refugee Studies 21, no. 4 (2008): 432-53; and Cathrine Brun, "Hospitality: Becoming 'IDPs' and 'Hosts' in Protracted Displacement," Journal of Refugee Studies 23, no. 3 (2010): 337-55.

29 Liisa Malkki, "National Geographic: The Rooting of Peoples and the Territorialization of National Identity among Scholars and Refugees," Cultural Anthropology 7, no. 1 (1992): 24-44.

30 Ahmed, "Home and Away."

31 Laura Hammond, This Place Will Become Home: Refugee Repatriation to Ethiopia (Ithaca, NY: Cornell University Press, 2004); Eastmond, "Transnational Returns"; Korac, Remaking Home; Stefansson, "Homes in the Making: Property Restitution, Refugee Return, and Senses of Belonging in a Post-war Bosnian Town," International Migration 44, no. 3 (2006): 115-39; Steve Jansen and Staffan Löfving, Struggles for Home: Violence, Hope and the Movement of People (Oxford: Berghahn Books, 2009).

32 Korac, Remaking Home, 25.

33 Eastmond, "Transnational Returns."

341951 Geneva Convention and Protocol Relating to the Status of Refugees, Article 1.

35 Eastmond, "Transnational Returns."

36 Katy Bennett, "Homeless at Home in East Durham," Antipode 43, no. 4 (2011): 960-85.

37 Korac, Remaking Home, 25.

38 Jeff Crisp, "No Solution in Sight: The Problem of Protracted Refugee Situations in Africa." Working Paper 68 (San Diego: Center for Comparative Immigration Studies, University of California, 2002).

39 UNHCR, "Protracted Refugee Situations: The Search for Practical Solutions," in The State of the World's Refugees: Human Displacement in the New Millennium, ed. Nada Merheb and Sean Loughna (Oxford: Oxford University Press, 2006), 106.

40 This policy term entered into usage in the 1970 and coincided with the shift of the majority of the world's refugees to non-European settings. It sets out three "solutions," in order of preference to the problem of people out of place: repatriation, local integration, and resettlement in a third country.

41 James Milner and Gil Loescher, "Responding to Protracted Refugee Situations: Lessons from a Decade of Discussion." Forced migration policy briefing 6 (2011).

42 High Commissioner Gerrit van Heuvan Goedhart called the remaining camps "black spots on the map of Europe" that should "burn holes in the consciences of all those privileged to live in better conditions." Ibid., 75 .
43 UNHCR. The State of the World's Refugees: In Search of Solidarity (Oxford: Oxford University Press, 2012), 105.

44 United Nations Relief and Works Agency for Palestine Refugees in the Near East, "Palestine Refugees," http:// www.unrwa.org/palestine-refugees.

45 The UNHCR has arbitrarily used the number 25,000, but this figure is gone in the 2012 iteration of the definition of PRS (thank you to Jennifer Hyndman for this observation).

46 U.S. Department of State, "Protracted Refugee Situations," http://www.state.gov/j/prm/policyissues/issues/ protracted/index.htm.

47 Milner and Loescher, "Responding to Protracted Refugee Situations."

48 For a discussion of such invisibility, see Gaim Kibreab, "Invisible Integration in the Greater Horn Region," in Regional Integration, Identity and Citizenship in the Greater Horn of Africa, Eastern Africa Series, ed. Kidane Mengisteab and Redie Bereketeab, 69-10o (Woodbridge, Suffolk: James Currey, 2012); Tara Polzer and Laura Hammond, "Editorial Introduction: Invisible Displacement," Journal of Refugee Studies 21, no. 4 (2008): 417-31.

49 UNHCR, "Protracted Refugee Situations."

50 Liisa H. Malkki, "Mass Displacement and Globalized 'Problems of Organization," Ethnology 3, no. 3 (2002): 355.

51 Ibid.

52 Merrill Smith, "Warehousing Refugees: A Denial of Rights, a Waste of Humanity," in World Refugee Survey, 38-56 (Washington, DC: United States Committee for Refugees and Immigrants, 2004).

53 Cindy Horst, "Globalization of Protracted Refugee Situations: Kenya Case Study Fieldwork Report,” IASFM Meetings, Cairo, January 2008, cited in Hyndman and Giles, "Waiting for What?," 362.

54 Exceptions may be found in the large U.S. resettlement program for 60,000 of the 107,000 Bhutanese refugees in Nepal since 1992; the ongoing project to close the camps in Nepal includes offers from Australia, Canada, Norway, the Netherlands, New Zealand, Denmark, and the United Kingdom to resettle some of the refugees. UNHCR 2010, "A Fresh Start: Refugees from Bhutan Arrive in the UK," 9 August 2010, http://www.unhcr.org/4c6026059.html. Another exception may be the naturalization of 17,000 Burundians in Tanzania, which continues at the time of writing. See UNHCR, State of the World's Refugees.

55 Hans Skotte, "Tents in Concrete: What Internationally Funded Housing Does to Support Recovery in Areas Affected by War; The Case of Bosnia-Herzegovina" (Trondheim: Norwegian University of Science and Technology, 2004).

56 "The Four Freedom Agreement guarantees to citizens from the two countries freedom of movement and residence, right to work and own property. It was signed in Cairo by former president Hosni Mubarak and Sudanese president Omer Hassan al-Bashir on 18 January 2004." "Sudan-Egypt Relations Hit Speed Bump over Four Freedoms Accord," Sudan Tribune, 24 February 2013. 
57 Karkabi notes that a recent decree (no. 14, 2012) caused panic. In the sections addressing the Sinai Peninsula specifically, the decree states that all Egyptian citizens holding a second foreign nationality or those who are descendants of at least one non-Egyptian parent, including all non-Egyptian citizens, must sell their rights to property (private or commercial) within six months.

58 Deirdre Conlon, "Waiting: Feminist Perspectives on the Spacings/Timings of Migrant (Im)Mobility," Gender, Place and Culture 18, no. 3 (2011): 353-60; Alison Mountz, "Where Asylum-Seekers Wait: Feminist Counter Topographies of Sites between States," Gender, Place and Culture 18, no. 3 (2011): 381-99.

59 Turner has been critiqued for his structuralist notions of society, and status systems as characterized by binary oppositions. His theorization of liminality as dialectical and society as constantly in transition nevertheless anticipates this thinking:

From all this I infer that, for individuals and groups, social life is a type of dialectical process that involves successive experience of high and low, communitas and structure, homogeneity and differentiation, equality and inequality. The passage from lower to higher status is through a limbo of statuslessness. In such a process, the opposites, as it were, constitute one another and are mutually indispensable. Furthermore, since any concrete tribal society is made up of multiple personae, groups, and categories, each of which has its own developmental cycle, at a given moment many incumbencies of fixed positions coexist with many passages between positions. In other words, each individual's life experience contains alternating exposure to structure and communitas, and to states and transitions. Victor Turner, The Ritual Process: Structure and Anti-Structure (Piscataway, NJ: Transaction Publishers, 1995), 97

60 Marita Eastmond, "Stories as Lived Experience: Narratives in Forced Migration Research," Journal of Refugee Studies 20, no. 2 (2007): 248-64; Barbara Harrell-Bond, "The Experience of Refugees as Recipients of Aid," in Refugees: Perspectives on the Experience of Forced Migration, ed. Alistair Ager, 136-68 (New York: Cassell, 1999); Liisa H. Malkki, Purity and Exile: Violence, Memory, and National Cosmology among Hutu Refugees in Tanzania (Chicago: University of Chicago Press, 1995); Korac, Remaking Home.

61 See also Tim Cresswell, In Place / Out of Place: Geography, Ideology and Transgression (Minneapolis: University of Minneapolis Press, 1996).

62 Malkki, Purity and Exile.

63 Carol A. Mortland, "Transforming Refugees in Refugee Camps," Urban Anthropology and Studies of Cultural Systems and World Economic Development 16, nos. 3/4 (1987): 375.

64 Hyndman and Giles, "Waiting for What?"

65 Ibid., 362.

66 Kibreab, "Invisible Integration."
67 Ibid

68 Giorgio Agamben, Homo Sacer: Sovereign Power and Bare Life (Stanford, CA: Stanford University Press, 1998), 40.

69 Tim Cresswell, "Towards a Politics of Mobility," Environment and Planning D: Society and Space 28, no. 1 (2010): 17-31; Nick Gill, Javier Caletrio, and Victoria Mason, "Introduction: Mobilities and Forced Migration," Mobilities 6, no. 3 (2011): 301-16; Hyndman and Giles, "Waiting for What?"

70 Ann Varley, "A Place like This? Stories of Dementia, Home, and the Self," Environment and Planning D: Society and Space 26 (2008): 47-67.

71 Henrik Vigh, "Motion Squared: A Second Look at the Concept of Social Navigation," Anthropological Theory 9, no. 4 (2010): 419-38.

72 Brun, "Active Waiting and Changing Hopes."

73 Henrik Vigh, "Wayward Migration: On Imagined Futures and Technological Voids," Ethnos 74, no. 1 (2009): 91-109.

74 We borrow the notion of "constellations" from Tim Cresswell, who talks about constellations of mobility "as a way of accounting for historical senses of movement that is attentive to movement, represented meaning, and practice and the ways in which these are interrelated" ("Towards a Politics of Mobility," 26).

75 Easthope, "Place Called Home."

76 See also Veena Das, "The Act of Witnessing: Violence, Poisonous Knowledge, and Subjectivity," in Violence and Subjectivity: Violence, Political Agency and Self, ed. Veena Das, Arthur Kleinman, Mamphela Ramphele, and Pamela Reynolds, ooo-ooo (Berkeley: University of California Press, 2000).

77 M. Agosin, "I Invented a Country," in Women in Exile, ed. Mahnaz Afkhami, 140-9 (Charlottesville, VA: University of Virginia Press, 1994); Desiré Kazadi Wa Kabwe and Aurelia Segatti, "Paradoxical Expressions of a Return to the Homeland: Music and Literature among the Congolese (Zairean) Diaspora," in New African Diasporas, ed. Khalid Koser, 124-39 (London: Routledge, 2003); Cameron Macauliffe, "A Home Far Away? Religious Identity and Transnational Relations in the Iranian Diaspora," Global Networks 7, no. 3 (2007): 307-27.

78 Victor Buchli, Alison Clarke, and Dell Upton, "Editorial," Home Cultures 1, no. 1 (2004): 3.

79 See Stef Jansen, "Homeless at Home: Narrations of PostYugoslav Identities," in Migrants of Identity: Perceptions of Home in a World of Movement, ed. Nigel Rapport and Andrew Dawson, 85-109 (Oxford: Berg, 1998); Nadje AlAli and Nicola Pratt, What Kind of Liberation? Women and the Occupation of Iraq (Berkeley: University of California Press, 2010); Juliane Hammer, Palestinians Born in Exile: Diaspora and the Search for a Homeland (Austin: University of Texas Press, 2009).

8o Daniel Miller, "Behind Closed Doors," in Home Possessions: Material Culture behind Closed Doors, ed. D. Miller, 1-19 (Oxford: Berg, 2001). 
(C) Cathrine Brun and Anita Fábos, 2015. This open-access work is licensed under a Creative Commons Attribution-NonCommercial 4.0 International License, which permits use, reproduction and distribution in any medium for non-commercial purposes, provided the original author(s) are credited and the original publication in Refuge: Canada's Journal on Refugees is cited. 